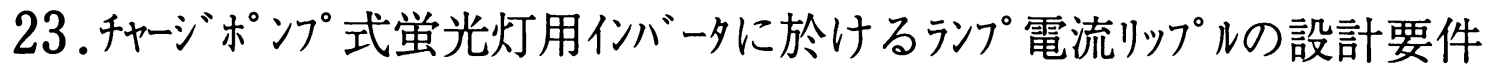

\author{
三嶋 正徳 前原 稔 \\ （松下電工株式会社）
}

\title{
1.はじめに
}

近年、商用電力系統の高調波障害を防止するため、照明機器には入力力率と入力歪に関して高い性能 が要求されており、これらの対策として現在では入力部にアクティブフィルタを用いるなどの様々な方 式が採用されている。

今回、簡単な回路構成で入力歪が改善できるチャージポンプ方式 ${ }^{12)}{ }^{2)}$ を提案すると共に、ランプ電流 のリップルを最小とする設計要件について検討を行ない、良好な結果が得られたので報告する。

\section{2. 回路構成と動作原理}

図 1 に基本回路構成を示す。本回路は、全波整流のハーフブ リッジ式インバータに、ダイオードDと、高周波で充放電を行う コンデンサC 2 とを付加しただけの簡単な構成である。

図中、C 2 端に発生する高周波電圧によって、電源 1 周期の 全区間にわたって入力電流を流すことにより、入力電流 I inを 正弦波に近づけることができるが、一方、設計が悪いとランプ電 流 I laに電源周期と同期したリップルが現われ、ちらつきなどの 問題を生じる恐れがある。

その設計要件を検討した結果、図 1 の破線及び一点鎖線で示す $2 つ$ 共振系が、重大な影響を与えていることが判った。すなわ ち、2つの共振系とは $\mathrm{L}-\mathrm{C} 3-\mathrm{R}$ 系（共振系 1) と、 $\mathrm{L}-\mathrm{C} 3$ - $\mathrm{R}-\mathrm{C} 2$ 系（共振系 2 ）で示されるが、これらは電源電圧瞬時 值に応じてその共振割合が変化するため、2つの共振系の出力に 差があると、ランプ電流波形 I laに影響が出てくるわけである。

図 2 に各々の共振系の出力特性を示す。この図で点灯周波数が flの場合にはランプ電流 I laは主に電源のピーク電圧付近の出力が 大きくなる波形となる。逆に、点灯周波数が $\mathrm{f} 2$ の場合には、電源 の $0 \mathrm{~V}$ 付近の出力が大きくなる波形となり、いずれもランプ電流 I laの波高率は悪い。そこで、2つの共振カーブの出力が等しく なる交点の周波数を点灯周波数 $\mathrm{f} 0$ とすることにより、共振系の違 いによるランプ電流の出力差をなくし、ランプ電流のリップルを 最小限に抑える設計とした。

\section{3. 実験結果}

図 3 に実験結果を示す。ランプ出力 $32 \mathrm{~W}$ 時、入力力率 0.98 、 THD8.6(\%)、ランプ電流波高率1.50という良好な結果が得られた。 4.まとめ

チャージポンプ方式の蛍光灯用インバータに於いて、2つの共 振系の出力がほほ同じとなる周波数を選ぶことにより、ランプ電 流 I laのリップルを最小にすることができた。

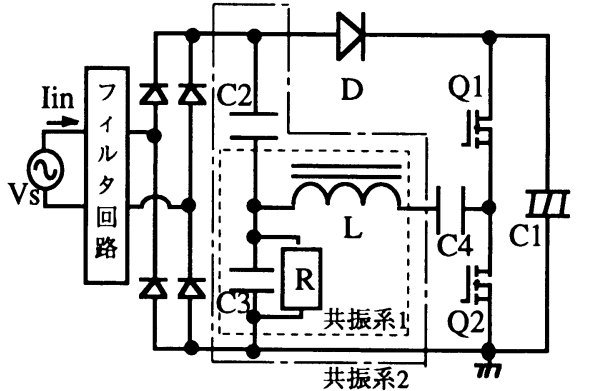

図 1 基本回路構成

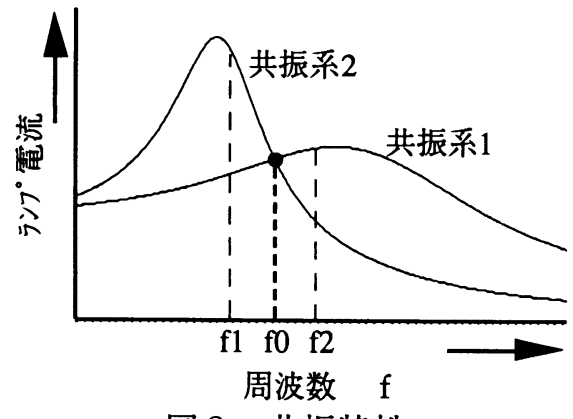

図 2 共振特性

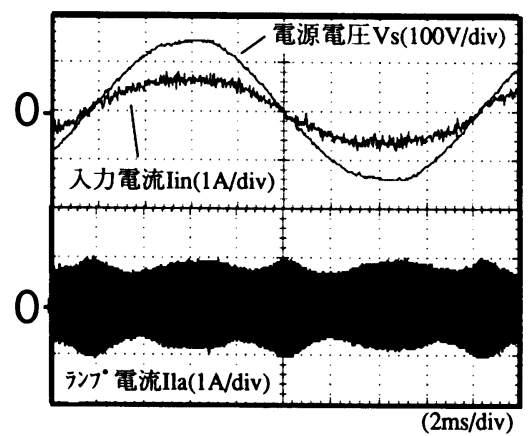

図 3 実験結果

\section{参考文献}

1）迫、他：入力高調波電流を低隇した蛍光灯インバータ回路の一検討 平成 7 年照明学会全国大会No. 15

2 ) Wei Chen,他 : Reduction of Voltage Stress in Charge Pump Electronic Ballast 27th Annual IEEE PESC

A consideration of Charge-Pump inverter circuit design for fluorescent lamps

Masanori Mishima, Minoru Maehara 